\title{
Financial Markets Barriers' in Agricultural Sector: Empirical Evidence of Iran
}

\author{
Seyed Jalal Sadeghi Sharif \\ Department of Accounting and Management, Shahid Beheshti University, Tehran, Iran \\ Tel: 98-91-2326-5034Ｅ-mail: Jsadeghi46@yahoo.com \\ Mahdi Salehi (Corresponding author) \\ Department of Accounting and Management, Zanjan University, Iran \\ Tel: 98-91-2142-5323 E-mail: Mahdi_salehi54@yahoo.com \\ Mehrdad Alipour \\ Management Department, Zanjan Branch, Islamic Azad University
}

\begin{abstract}
This paper aims to examine the relationship between financial market development and agricultural sector in Iran. The study attempts to answer these questions empirically and try to shed some light on the roles of financial development as well as other conditional variables in agricultural sector. The results of this study shows that the financial market in agricultural sector, however there is some weakness still. The authors come to conclusion that for improving this vital sector in Iran the weakness should be removed or at least reduced as early as possible.
\end{abstract}

Keywords: Financial market, Agricultural sector, Iran

\section{Introduction}

Iran is primarily an agricultural country. The agricultural sector makes a significant contribution to the national economy and is an important source of employment. Iran has a total area of 1,648,000 square kilometres, of which approximately 60 million hectares is potentially capable of supporting agriculture. Out of 51 million hectares only 18 million hectares are cultivated at the present time (Yazdani, and Vaezi 2008). In view of the fact, griculture is a significant economic sector in the national development framework of our country and plays a vital role in our national development. Those determinants are required for any further developments. To improving agricultural sector in Iran it is essential to establish some condition such like financial condition or financial market. Financial market plays a crucial rule in economic development process of Iran. It capitalizes entrepreneurs to undertake new investments or adopt new technologies. It helps smooth consumption by providing working capital and reduces poverty in the process. Following the revaluation in 1979 the government adopted various policies, which encourage farmers to improve their productivity and food self sufficiency has been a national priority. Following the 1979 revolution, replacement of the traditional interest based credit system with an Islamic credit system was one of the fundamental changes in Iran to ensure an adequate flow of credit, financial institutions reform was made to increase budgetary allocations. Credit for agriculture is channeled at below market interest rates, through Agricultural Bank, the major supplier of rural credit (80\%). The Bank has disbursed in 2001 approximately 1 million credit facilities amounting to 10.7 trillion Rials (14\% of agricultural GDP for the same period). Of this amount, $34 \%$ was in the form of payments for special projects approved and provided for by the government. About two-thirds of the total credit to the sector is granted to farmers engaged in field crops and horticulture. With a growing recognition of the importance of agri-business activities to promote development in the sector, there has been an increasing trend in the facilities offered to agricultural related industries and services.

The main objective of this research is studying the power of insuring financial \& credit needs of rural and agricultural sector and establishing organization that can cover these needs desirably. The main result of this problem is helping to increase the power \& potential of rural \& agricultural sector \& appearance of talent \& use their capacities. So, if covering financial needs about insuring machinery, loan, seed improvement, improve fields and etc. This sector will be 
able to grow, develop \& have sustainable job making like other economical sectors of society. The importance of this study is if needs of rural \& agricultural sector that is allocated an important part in population aren't realized, it has been remaining in traditional level \& doesn't have any role in self-sufficiency \& freedom of country's agriculture. Immigrating to other cities, stopping agricultural activities, depending to imports \& increasing of unemployment are effective factors of not attention to this important issue. Improving of financial organizations is one of the necessities of developing rural $\&$ agricultural sector that are said before. But, what's very important is improving tools $\&$ strategies $\&$ coordination between organizations. For example, guess that agricultural bank is paid loan with a low interest rate to farmers for tractor. So far from, farmers predominately don't have the ability of paying deposit \& them interest to accept that bank receive their tractor document as deposit. Whereas, various tractor aren't currently pagination by police station $\&$ it isn't accepted as loan deposit. So, it has seen that exposure of strategy for removing of these problems is so important. Other example is determining the importance \& necessities of this research. One of the most vulnerable groups of society's population is farmers \& they are -usually had lower literacy level and awareness than other population. This people generally don't be able to insure their financial problem in planting \& harvesting. So, they perforce \& because of financial pressure borrow money through informal channels \& some people like comparators in markets \& other people that are be able to insure money for them if they receive deposit $\&$. In the time of harvesting crops according to contract that they are hold it previously, crops are sold \& money is paid to people or crops are sold in lower price than other time and get it to solicitor. According to above context whether can we hope to discuss about saving for farmers? This procedure is repeated annually and farmers also become weaker in financial issues each year than previous year. So that, attention to practical formal strategies for insuring financial issue of this people can not be undeniable that existence of agricultural sector in country depend to it.

\section{Review of literature}

The government also adopted an economic model combining the objectives of food self sufficiency with those of liberalization and private sector promotion.

A Five-Year Socio-Economics Development Plans for reconstruction were launched, which aimed at increasing production, raising productivity in key economic sectors and promoting the non-oil export sector. Economic liberalization was pushed forth in the context of a national structural adjustment program which included correcting price distortions, floating the foreign exchange rate and promoting the private sector. During this period, Iran's agriculture expanded at strong growth rates, and the Plan's ambitious quantitative objectives were achieved to a large extent. A great number of theoretical and empirical studies have explored the sources of economic growth at both national and provincial levels (Yazdani 2001, Chandavarkar 1992, Carter 1988, and Chen and Feng, 2000) and ongoing debate is mainly concerned with which source, factor accumulation or productivity improvement, is the key growth-driving factor. However, unfortunately, the role of financial development in economic growth has till recently often been ignored. Christopoulos and Tsionas (2004) reviewed studies are subject to limitations such that the capital formation is the only additional growth-determining variable incorporated in the framework. Schumpeter (1911) points out the role of financial intermediaries in mobilizing funds, evaluating and selecting projects, managing risk, monitoring entrepreneurs and facilitating transactions as the critical elements in fostering technical innovation and growth. Under the assumption that the size of a financial system is positively correlated with the supply and quality of financial services, Gerdin (2002) documents a positive correlation between the financial development and productivity.

By the way, a large body of empirical studies supports the point of views that financial development may raise savings rate, stimulate investment, avoid premature liquidations of capital, reduce the cost of external finance, enhance the efficiency of capital allocation and insure more productive technological choices (King and Levine 1993, Amable and Chatelain 2001).

There are growth theory models that consider credit sources as a source of growth, Edwards (1993). Development in credit market creates incentives for farmers to improve productivity and results a growth in their GDP" Lal and Rajapartirana (1987).

Yazdani (2008) in the study the long-run relationships among financial development, growth and other key growth factors empirically examined in Iran's agricultural sector. He also the causality between financial development and GDP growth was evaluated. The robustness of his empirical results has been tested using different indicator of financial development. Overall, he found that financial development, capital stock, international trade and real interest have significantly impact on agricultural growth.

\section{The history of stock Exchange in Iran}

Tehran stock Exchange (TSE) was established in 1967. This organization is started its activities by doing several sales on dividend industrial and mineral bank. After that, Pars oil organization, public portfolio, treasure house documents, and public portfolio of improving industrial ownership organization gone to TSE. Conferment of fiscal excuse of acceptable organizations in stock market has an important role in creating motivation for preferring portfolio. While 11 
year the activity of stock market before revolution of Iran the number of organizations, banks and acceptable insurance organizations is increasing from six economical institutions with 6.2 milliards Rials capital in 1967 to 105 institutions with 230 milliards Rials in 1978. Also, the value of exchanging in stock market is increasing from 15 millions Rials in 1967 to 150 milliards Rials in 1978. In the years of after revolution \& before the first program of 5 year economic development has made memorably changes in national economic that is included Tehran's stock markets. The first circumstance was authorized of law essay of controlling banks works on 17 in 1979 by revolution council that according to it country's commercial \& professional banks in the frame of nine commercial banks and three professional banks are integrated. Some time ago insurance organizations also are integrated together and they are became public ownership \& also authorized of law essay of protecting and improving Iran's industrial in 1979, further, it caused that most of acceptable economical institutions on stock market is stopped. So, its number is decreased from 105 organizations \& economical institutions in 1979 to 56 organizations on the end of 1988. Therefore, through these years stock market become weaker until the end of 1988. In 1987 the frame of the first program of 5 year economic development repetition activity of TSE is considered as the basis of performing privatization policy. So, politicians are considered that stock market transfer parts of their activity from public sector to private sector, capital absorbing and collecting outspread saving resources and directing it to investment consumption for mobilization of economical development resources and effective motivation of private sector for actively participation in economic activities. At all events, tending through economical macro investments to use activities stock market, increasing the number of acceptable organizations and increasing activities volume is included TSE that according to it over the years of 1988 until this year the number of listed companies in TSE is increased from 56 organizations to 325 organizations. In among a policy about increasing the number of exchanging dividend centre in all part of country is created. So that, stock markets of Mashhad, Tabriz, Isfahan and Ahvaz is established so these centres are communicated directly to Tehran's centre and this local stock markets plus exchange their area dividend has the ability of TSE. This effectiveness is so high that nowadays Mashhad's stock market is parallel with TSE and we can see exchanging volume growing. Acceptable organizations and active organizations in stock market are divided to two groups:

Manufacturing organizations

Investment organizations

Manufacturing organizations usually is produced special goods and they put in active industry in stock market and in stock market organizations and identified with organization name and special code. But, investment organizations is organization that operates as financial mediums that this kind of organizations don't have manufacturing activity or their activity is some thing like activities that perform by financial helps through buying manufacturing and industrial organizations dividend or group of them are investing or producing in this organizations, so according to it nowadays active investing organizations in stock market are 29 organizations and manufacturing organizations are 310. Also, necessities field for attending servicing organizations in stock market are prepared.

Exchanging volume procedure, Tehran's stock market inefficiency and whole market volume:

Expanding culture of investing \& participating in one hand and special character of stock market (the ability of absorbing minor capitals) in the other hand are caused growing TSE.

\subsection{Local stock market}

One of important stock market development programs in lately years is started local stock market out of Tehran. Physical and quantity capital development had an effective role in developing investment culture. So that, according to this situation establishing grounding stock market and goods in various towns and provinces of Iran can be helped to support agricultural and rural sector of Tehran in using existence opportunities.

Agricultural goods stock market

Agricultural goods stock market is started its activity as second goods stock market in Iran on summer of this year and it has effected on activities procedure and developing capital market of Iran and presenting agricultural crops. Agricultural goods stock market is started its activity on 2004 by Jihad ministry \& directed by Tehran's stock market through grounding network. This stock market is established for covering all agricultural \& rural crops. But, nowadays because this stock market starts its activity lately and it can't expand \& develop stock market culture among various population of agricultural \& rural society it just can exchange crops such as wheat, rice, oat, maze, white sugar, meal, bean \& pistachio in this market. The basis of this stock market is consisted of stock market council, agricultural stock market governing, preceptors and groundings organizations. Agricultural goods stock market has spend a lot of time for changing to goods stock market. Government can protect agricultural stock market in various ways, because government doesn't receive any tax from traditional market activities \& if it actively excuses this market from tax, motivation of this people will increase. Government is insured households'. Consumption items that can perform its recommendation through stock market, some of items that exchange in stock market are such as meal \& corn that 
nowadays our country is imported them that government can create motivation with depreciation in dutiable items \& dues for market workers.

\subsection{Agricultural regional goods stock market}

It must say that for creating centres in regions that present agricultural crops agricultural stock market statute station and deputations in townships that after activation and prosperity of stock market in manufacturing centres some deputations is inaugurated. For that reason, agricultural banks are acted as agricultural stock market. Also, if extensive cooperatives network have gain enough information, agricultural crops can present. The first studies are shown that bank must do feasibility for identifying possible situations. In 2004 agricultural goods stock market is started its activity in Gilan province and Rasht city as the first deputation of agricultural goods stock market. Nowadays agricultural goods stock market is acted just about internal sales and it doesn't act for imports and exports. But, it is able to create healthy atmosphere for imports \& exports of agricultural goods, so external investors can provide its goods from this market. And how, from starting agricultural stock market there isn't any external volunteer from abroad but, the ability of this kind of exchanging in stock market is created \& there isn't any proscription for external customers in stock market. Existence of this kind of customers is necessary for stock market but its better that internal outgoings enter to markets themselves \& do this kind of business. Presenting goods are guided customers to one centre. This situation for agricultural goods stock market is one of the positive points that are caused competition and transparency the real price of goods. One of the agricultural stock market problems is high presentation \& low demand. The result of this problem does not know about stock market works \& existence of traditional market.

\section{Objectives of the study}

The main objective of this study as follow:

1) Recognition and awareness of farmers financial difficulties in rural of Iranian environment and exposure this problems to organizations that have the role of performing supportive policies of agricultural sector for insuring of doing better service to this sector.

2) Necessity of establishing and introducing micro financial markets in rural place of Iranian environment.

3) Recognition and awareness of farmers about creating micro financial systems in rural place spontaneously

4) Creating necessary fields'; for informing about how farmers can use bank resources and feasibilities.

Changing in general view of to this sector $\&$ this part is the most necessary $\&$ important multi sectors of country.

\section{Research questions}

Micro-credit financial organizations (non-bank organization that have the ability of covering financial needs of rural sector of country and improving this sector can effect on improving rural and agricultural sector of country) have formal, informal nature and in Iran most of the time we can see informal nature of them. These questions will help to receive the goal of research. So, these questions are:

1) Whether country's improving financial markets in rural \& agricultural sector and improving monetary and financial organizations in this sector can cause to improve and grow this sector?

2) Whether improving monetary markets will have a role in improving Iranian rural and agricultural sector?

3) Whether improving financial markets will have a role in improving Iranian rural and agricultural sector?

Which financial markets have more roles in improving Iranian rural and agricultural sector?

Whether non bank organizations (micro) have the ability of covering financial and credit needs of country's rural and agricultural sector?

\section{Research hypotheses}

According to above research problems and literature the hypotheses which postulated in this study are as follows:

Financial market covers rural and agricultural financial needs in Iran.

Development in financial market causes enrichment in Iranian agriculture sector.

Agricultural sector if eligible take loans vey easily.

Long term process at the time of taking loans cause to weakness of financial market in Iran.

Lack of awareness of financial market service leads to decrease in financial supporting of agriculture sector in Iran.

\section{Research methodology}

The research methodology used in this study is based on both survey and description methods. So far accurate answer to the research questions, the authors design and developed a questionnaire which it is the most suitable for this study. A survey questionnaire was completed by the agricultural sector at the end of March 2009. The questionnaire contains two 
parts namely (A) bio-data and (B) this section includes several questions regarding to the quality of services which rendering in Iran. Five-Point Likert's Scale questionnaire was employed in this research. The Five-Point Likert's scale having the ratings of "strongly disagree" (1) and "strongly agree" (5) were used.

First the researchers must determine sample size among member of statistical population. For that, all villages of Tehran province are considered according to population information of townships of Tehran province in 13 townships. After that, we choose 11 villages and 80 villages are chosen for final sample. For choosing villages of each township is used random sampling so, each village has the equal chance in its group for choosing. For that, at first the names of villages of each township are written on cards \& put them on bung \& pull 5 cards out of bung randomly. In total, 650 questionnaires were distributed among the farmers in various villages in Tehran province. Out 650 questionnaires, 582 useable questionnaires were returned by farmers ( 89.54 per cent). So, the interest of participants stood at $89.54 \%$ which it seemed high. Table 1 shows bio data and general information of participants.

As Table 1 shows the majority of participants are male with 74.05 per cent and the least number of participants are female 151 participants. Regarding to educational background, majority of participants have got Diploma (300 numbers) followed by illiterate fellows 31.79 per cent. Moderate number of participants has got B.S which stood at 13.92 per cent. It is interesting to note that the least part of participants has got M.S. It is because of either they graduated in agricultural field or because of unemployment they have to do this kind of works.

Insert Table 1

Regarding to participants' age, majority of participants' ages were between 30-40 years old which stood at 35.74 per cent, followed by the participants with ages of 41-50 which stood at 34.36 per cent. Least number of participants had more than 51 years old which stood at 12.37 per cent.

Regarding to per month salary least number of participants had more than $\$ 500$ per month; moderate number of participants had \$ 301to 400 per month; followed by 34.71 per cent had \$201-300 per month. In is also interesting to note that 19.07 per cent of participants had salary about $\$ 100-200$ per month. To conclude, majority of participants were male; they got diploma degree; majority were young fellow with middle salary per month.

\section{Testing of hypotheses}

In order to testing of five hypotheses in this survey, the fittest test to study were employed, in other words, T-test were employed in this study, further to better catching the heart of the each hypothesis point's, Mean value and Standard Deviation (S.D) of each hypothesis is calculated. Table 2 shows the results of testing hypotheses.

H1: Financial market covers rural and agricultural financial needs in Iran.

The first hypothesis is directed to the ability and effectiveness of financial services which renders by financial markets to rural and agricultural sector in Iran. As it shown in Table to the mean degree of this hypothesis is stood at 2.15, S.D is 0.699 . The result of $\mathrm{T}$ test is 39.836 and the significance level is 0.000 . So, according to these results the first hypothesis is strongly accepted and null hypothesis is rejected. In other words, Iranian financial market is covers several needs of rural and agricultural sector in Iran.

H2: Development in financial market causes enrichment in Iranian agriculture sector.

Second hypothesis is related to financial market affection to Iranian agricultural sector which Table 2 shows the results of testing second hypothesis.

According to below table, Mean value of second hypothesis stood at 2.48, S.D is 0.721 .

The result of $\mathrm{T}$ test stood at 31.236 and significance level is 0.000 which according to those results this hypothesis also strongly accepted. In other words, development of financial market has positive correlation with Iranian agricultural sector. So, it can conclude that for developing agricultural sectors besides other factors, we can improve financial market also.

H3: Agricultural sector if eligible take loans vey easily.

Third hypothesis is related to period of loan requesting to loan taking by agricultural sector. According to the results of Table 2, mean value of third hypothesis is 2.32 , S.D is 0.701 . The below table also reveals the results of $\mathrm{T}$ test for third hypothesis stood at 18.301 which significance level is 0.000 . According to these results the third hypothesis is strongly accepted and null hypothesis rejected. As it mentioned earlier Iran is agriculture country and it has preference in some agricultural items in the world. One way for improving Iranian economics is enlarging as well as enriching agricultural sector in Iran. For this purpose the agricultural sector should finance in short time and easily; according to the result of third hypothesis is it happing in Iran.

H4: Long term process at the time of taking loans cause to weakness of financial market in Iran. 
The fourth hypothesis is directed to bureaucracy and formality process of loan taking and it difficulties. According to the results of fourth hypothesis this hypothesis is also strongly accepted; in other words, from the view point of participants, the major problem is formalities at the time of taking loans.

Insert Table 2

Last not the least the authors come cross with testing the fifth hypothesis which is:

H5: Lack of awareness of financial market service leads to decrease in financial supporting of agriculture sector in Iran.

According to the results of Table 2 the mean value of fifth hypothesis was 2.68; S.D was 0.719 and T test result stood at 21.361 with significance level of 0.000 . With reference to these results this hypothesis also accepted and null hypothesis is rejected. In other words, the lack of awareness of financial market services by users leads to decreases in financial supporting of agricultural sector in Iran.

\section{Conclusion}

Agriculture is an important component of Iran's economy. The agricultural sector accounts for one fifth of GDP, and employs one third of the labour force. Food processing (particularly sugar refining and vegetable oil production) also is an important industrial sector. With its large population and limited arable land, Iran is not self-sufficient in food, and is a major food importing country in the region.

However, Iran enjoys a wide diversity of climate and terrain, enabling its farmers to produce the traditional staple cereals (wheat and barley), rice, sugar beets as well as tobacco and tea. It is the world's largest exporter of high-quality pistachio nuts. Over the last decade, as part of a policy to generate non-oil export earnings, the government has promoted the expansion of export-based specialty products such as pistachios, dates, and flowers by bringing large-scale irrigation projects online. These and other efforts sustained a healthy economic growth in the agricultural sector in the 1985-1998 period, marked by increased yields and additional land put into cultivation. By the mid-1990s, Iran was importing just $5 \%$ of its wheat, rice, vegetable oil, sugar, and meat needs. According to the results of this survey, Iranian government is emphasising to agricultural sector which the main proof is developing financial market to this area. The results of test of hypotheses showed that this financial market also plays very important role in developing agricultural sector in Iran. By the way, the results also indicated that there is still some weakness in such a financial market. The authors came to conclusions that for removing or at least reducing such weaknesses at first stage the bureaucracy of taking loan as much as possible should be reduce and second more advertisement is needed by such financial market to the users; in whole to the Iranian society.

\section{References}

Amable and Chatelain, B. Amable and J.B. Chatelain. (2001). Can financial infrastructures foster economic development? Journal of Development Economics, Vol. 64, pp. 481-498.

Carter, M.R., (1988). Equilibrium credit rationing of small farm agriculture, J. Develop, Stud, Vol. 28, pp. 83-103.

Chandavarkar, A. Chandavarkar. (1992). Of finance and development: Neglected and unsettled questions, World Development, Vol. 22, pp. 133-142.

Chen and Feng, B.Z. Chen and Y. Feng. (2000). Determinants of economic growth in China: Private enterprise, education, and openness, China Economic Review, Vol. 11, pp. 1-15

Christopoulos and Tsionas, D.K. Christopoulos and E.G. Tsionas. (2004). Financial development and economic growth: Evidence from panel unit root and cointegration tests, Journal of Development Economics, Vol. 73, pp. 55-74.

Gerdin, A. (2002). Productivity and Economic Growth in Kenyan agriculture, 1964-1996. Agricultural Economics, Vol. 27, No. 1.

King and Levine, R.G. King and R. Levine. (1993). Finance and growth: Schumpeter might be right, Quarterly Journal of Economics, Vol. 108, pp. 717-737.

Lal, D. and S., Rajapatirana. (1987). Foreign trade regimes and economic Growth in developing countries. World Bank Res. Obs., Vol. 2, pp 189-218.

Schumpeter, J.A. Schumpeter. (1911). The theory of economic development, Harvard University, Press, Cambridge, MA.

Yazdani Saeed. (2008). Financial Market Development and Agricultural Economic Growth in Iran, American-Eurasian Journal of Sustainable Agriculture, Vol. 2, NO.3, pp. 338-343.

Yazdani, S and L, Vaezi. (2008). Comparison of Agricultural Producer Support in Iran and Selected Countries, American-Eurasian Journal of Sustainable Agriculture, Vol. 2, No. 3pp. 344-350.

Yazdani, S. (2001). Factors Affecting on Agricultural Growth in Iran. Journal of Jahad, Vol. 24, P. 2. 
Table 1. General information of participants

\begin{tabular}{|c|c|c|c|}
\hline Item & Sex & Frequency & Percentage \\
\hline \multirow{2}{*}{ Gender } & Male & 431 & $74.05 \%$ \\
\hline & Female & 151 & $25.95 \%$ \\
\hline \multirow{4}{*}{$\begin{array}{l}\text { Educational } \\
\text { Background }\end{array}$} & Illiterate & 185 & $31.79 \%$ \\
\hline & Diploma & 300 & $51.54 \%$ \\
\hline & B.S & 81 & $13.92 \%$ \\
\hline & M.S & 16 & $2.75 \%$ \\
\hline \multirow{4}{*}{ Age } & Less than 30 & 102 & $17.53 \%$ \\
\hline & Between 30- 40 & 208 & $35.74 \%$ \\
\hline & $41-50$ & 200 & $34.36 \%$ \\
\hline & Above 51 & 72 & $12.37 \%$ \\
\hline \multirow{4}{*}{$\begin{array}{l}\text { Salary (per } \\
\text { month) in US } \\
\$\end{array}$} & $100-200$ & 111 & $19.07 \%$ \\
\hline & $201-300$ & 202 & $34.71 \%$ \\
\hline & $301-400$ & 200 & $34.36 \%$ \\
\hline & Above 500 & 69 & $11.86 \%$ \\
\hline
\end{tabular}

Table 2. The results of testing hypotheses

\begin{tabular}{|l|l|l|l|l|l|l|}
\hline Hypotheses & Frequency & Mean & S.D & T- Test & Sig. & Results \\
\hline H1 & 582 & 2.15 & 0.699 & 39.836 & 0.000 & Accepted \\
\hline H2 & 582 & 2.48 & 0.721 & 31.236 & 0.000 & Accepted \\
\hline H3 & 582 & 2.32 & 0.701 & 18.301 & 0.000 & Accepted \\
\hline H4 & 582 & 2.81 & 0.739 & 19.412 & 0.000 & Accepted \\
\hline H5 & 582 & 2.68 & 0.719 & 21.361 & 0.000 & Accepted \\
\hline
\end{tabular}

